\title{
The Countermeasure Effort of Child Delinquency Not to A Legal Case in Criminology Perspective
}

\author{
Abnan Pancasilawati ${ }^{1}$ \\ \{abnanpancasilawati@gmail.com ${ }^{1}$ \} \\ State Islamic Institute of Samarinda, Indonesia ${ }^{1}$
}

\begin{abstract}
The Child is 12 to 18 years of age and not married yet. The child is considered that has not knowledge but also has a unique and exclusive personality. Child's world is the dream world so that he can not differ from the real world. The child also a great imitator, so he able to imitate adult action. In the growth time, child experience puberty which is identical with identity finding. It's the critical point of a child to show existence, in the social world of his family as well as intercourse environment because they will be showing to existence for his family and his social environment. Over exist of children make his behavior personality can deviate from society older than called juvenile. At the and the behavior can violate legal, religion and cultural norm. The implication is the child can be labeled as rude, the religious called the cursed child and the law called a crime perpetrator. Juvenile Court is regulated under Law Number 3 the Year 1997 Article 1 section 2 Brat is: a. A child who commits a crime b. A child who commit acts that are prohibited for children, either by law or other norms in society. Any crimes committed by and hence chargeable to a crime perpetrator, even it is a light crime. The criminology study can see a crime perpetrator, how child commits a crime. The study can analyze how a child does a commit crime and then find a solution of prevention effort in order the child not get a legal case.
\end{abstract}

Keywords: The Countermeasure Effort, Child Delinquency.

\section{Introduction}

Indonesia is the largest population state, on July $1^{\text {st }} 2015$, it is $255,461,700$ or $3.45 \%$ of world population. This can be problem and challenge. Therefore the state has authority to regulate. If the state cannot manage, it will increase unemployment and at the end, family welfare decreased. This impacts to parent attention on their children. The over existence of children make their behavior can deviate from norms.

Globalization era has no good effect because foreign culture will influence the child behavior. So, he is able to imitate foreign culture which fell dashing. Development of science and technology has an influence on insight and thought. On the other hand, the development can open negative content which can not be prevented by the government, like pornography, hoax and else. This impact can harm their behaviour.

A Family is a small group of people consist of a father, mother and children (Law Number 4 the Year 1979 about the child's welfare). The small group is an entity who cannot be separated from father, mother, and children. Everybody in this family has a right and obligation to guarantee their survival. Parent have a role to children, so they give education and guiding according to values and attitudes regarding morality to their children. 
when the child has entered the period of puberty which is the phase of identity searching. The child's puberty is 8 to 16 years in age. This is the period of their hormones begin to develop so the voice changes, the feather grow in certain places and women have menstrual experience. This is according to knowledge which increase and begin identity molding. All of them will arise problems began by seeking for attention both from family and social environment. If the attention is not gotten, so he against every obstacle he face. Uncontrolled action will violate customary, social and legal nomrs that are called mischievous and when violates the law is crime perpetrator

Managing a naughty child problem is not easy. This mainly, in developing countries, children are not ready to accept such rapid changes. In one side, the child has strict behavior through culture environment who become their personal self, so he has established a certain contradictory attitude to change whatever. The soul of a child is unstable attitude and easily influenced by something that comes to him, which often leads conflicts in his environment. It will influence their behavior and posess a problem to the environment which they live and also to themselves.

Children behaviour is uncontrollable by norm and law, this is mischievous, if he cannot control, although age is still considered immature, his actions can injure other people, so the children can violate law. The problem of child delinquency is not the only problem of national law in particular state but it is a legal problem of all countries in the world or global problem. Many delinquencies are contrary to the law which occur within the community. This must be put attention seriously law enforcement from officials and the community.

The mass media show concrete facts of child behavior such as brawl among student, villages, drunkenness, drugs, inconsiderate in driving a vehicle, a student is pregnant out of wedlock and others. Therefore, parents and all parties should be careful and always give education and guidance to their children.

In general, causes of child mischiefs not only his own but also parent role mistake to educate or too hard, too indulgent, environmental influences and others. To overcome this problem not only focus on juvenile, but also parents must give an understanding and guidance on appropriate education and always provide monitoring so that morally damaged.

The increasing of child delinquency and violence occurred in Indonesia, so that it would damage child mentality. Violence is a way to resolve conflicts practically. Violence must be solved so that it cannot entrench community.

Will Indonesia children grow and develop into a great generation?. Thus it takes an effort to overcome child's mischief and one of them from criminology perspective.

\section{Discussion}

\subsection{Children has a unique}

Humans are a mystery whose difficulty to guess because they are a dynamic person, and act on both empirical and psychological stipulations. Human nature changes always because of abstract human nature and depends on the conditions. If conditions are not favorable so directly turns to act differently.

The Child is 12 to 18 years of age and not married yet. The Children as a human being who has a mysterious person, unique and exclusive. They are the next generation who forwards leadership of the nation and state. Therefore they need education by related parties included parent, community, and others. The children cannot be independent yet, so related 
parties must realize children welfare in growth and development spiritually, physically and socially. As a person needs consideration both clearly and precisely. Thus, children become an independent people.

Children behavior is changeable who is not the same as adult. The children also a great imitator, so they are able to imitate adult action. Many aspects resolve on child problem like criminology approach. This approach prevents the brat so they spare the law. However, if they violate law, so they are treated who conform is age and no as adults.

Children have a unique personality who try to adjust the circumstances in their environment, they can do without thinking, like protection of themselves from threats or act which violate of the norm, religion, and law called brats.

The kind of deviation/ delinquency has relation with a rampant culture of violence among children as follows;

1. races on streets that interfere traffic security, and endanger themselves and others

2. Impulsive behavior, rigidity, disrupt the environment. This behavior is caused by excessive energy and cannot control and terrorizing the environment.

3. Fighting between gangs, groups, schools, tribes and thus effect casualties

4. Skipping school to gather on the street, or hiding places in doing immoral acts..

5. Dangerous acts, intimidation, extortion, robbery, stealing, pickpocketing, robbing, others.

The problem of violence is an aggressive action which can act such as hitting, poking, kicking, slapping, punching, biting, all forms of violence. Although violence is a normal action, the same action in a different situation will violate norm, religion, and law named deviation.

Violence can damage both physical or psychological. This violates regulation called a crime. Thus, the term of violence is more obvious which show a crime who violate the law.

Delinquency of children is detrimental to society. There are 2 (two) forms of motivation who a person or group moves to perform a misconduct because want to achieve the desired or satisfied actions namely intrinsic and extrinsic motivation.

1. Intrinsic Motivation of Child Delinquency

a. The Factor of intelligence

The factor of intelligence is ability to acquire and apply knowledge and skills. Meaning an ability to weigh and make decisions. In general, the delinquency of these children have lower verbal intelligence, this effect such as miss out on lower school achievement so that social insight is less sharp, and cannot know either good or bad of action.

b. The factor of age

The factor of age influence to commit of crime. Children of age behave as children who assume the world is a game, but different behavior can commit both offenses or crimes.

c. The factor of Gender

Law is not distinguished between the sexes of men and women because both sexes have potency for naughty. But the men do more evil and women will be victims of sexual harassment and casualties

d. The factor of child position in family

The order of birth influence of a child in family, such as first child, second and so on. usually for single children is spoiled. The standard cannot be applied because all 
wishes are fulfilled. As a result, it can not adjust other environments. If the child cannot adjust, so can desperate, finally commit a violation or a crime.

\section{Extrinsic Motivation Of Child Delinquency}

a. The Factor of Family

The child growing in a lovely family is different from them who grow both in a rough family and broken home. The increasing of crime and delinquency because social control doesnot function well by family and society. Thus, the family fails to educate children, this causes them act of deviation that social sanctions imposed by society.

b. The factor of education and School

School is an education and media for child who interacts each other or intermediary for development of children soul with the teacher. Schools have responsibility for the education of children, whether scientific education or character education. The inability interacts with the school so create negative of effects for the child mentality development, thus the child commits a deviation behavior.

c. The factor of Child interaction

The parent must know about influence by the social environment to children If the child friends like to behave deviation so the child will commit deviation. The child does not follow so be ridiculed and humiliated.

d. The Influence of Mass Media

The mass media has an influence on the development of children. The child commits a crime which is caused such as of the influence of reading, inappropriate images, films of violence and pornography. For a child spends his spare time to commit which deviate from an action, it will be dangerous for child's future.

\subsection{The Child Delinquency Is A Stigma}

Mischief is a stigma given to a child when the child not follow norm. The child commits anything without realizing whether the act injure him or others. The brat has different both between individuals and cultures. This means that children's delinquency problems and standards are different and it is strongly influenced by individual perceptions and culture. This view of difference is called relativism. Relativism sees that an acquaintance should not be universally assessed but the concept of delinquency must be judged by the value of the individual or the culture itself. An act is called naughty by one individual but not for another individual. Likewise in the cultural context, an act was called naughty but not called brat by other cultures.

Childhood is a turbulent time. At this time the behavior can change quickly. This change is caused the burden of homework, school work, or daily activities at home. Despite the behavior of child change rapidly, it is not a psychological problem.

Children show their existence to others because they assume that other people admire or criticize them, as same as they admire or criticize themselves. The assumption makes confidence increase. For girl will dress up for hours in front of the mirror because believes that people will glance and are interested in her beauty. While boy try to looks unique and great so he believes whoever is an impress.

Children often think of themselves as capable, so they do not think of the consequences of their actions. Impulsive actions are often performed because they are unconscious and unknow the effects. 
The concept of age regulation in Indonesia is diverse which depend on which law is used.

Because the child's age is conditioned by the rule of law. the Act of Indonesian regulate the children under age or immature.

Based on the above, the age limit used in Indonesia's positive law and other legislation, including:

1. Article 330 of the Civil Code: immature is those who have not reached the age of 21 years and are not married yet.

2. Law Number 1 The Year 1974; Marriage is the prospective bride by marriage law must have reached of 19 years old of men and 16 years old of women.

3. Act No. 3 of 1997 on Juvenile Court: the child is a brat in the case who has reached the age of 8 (eight) to 18 (eighteen) years old and has never married.

4. Law Number 23 The Year 2002 regarding Child Protection: a child who is not yet 18 (eighteen) years of age, including a child who is still in the womb. ${ }^{1}$

Understanding the delinquency of child can be known on the definition what is meant by child mischief, as quoted from the book Romli Atmasasmita (1983), ${ }^{2}$ that any act or behavior of a person under the age of 18 years and not married yet which is a violation of legal norms in effect and may harm the child's personal development.

Meanwhile, according to Article 1 point 2 of Law Number 3 the year 1997 concerning Juvenile Court, mean by brat is:

1. A child who commits a crime

2. A child who commit acts that are prohibited for children, either by law or other norms in society.

Crime and delinquency of children cannot be separated by the context of the sociocultural conditions of his day, because at each period is characteristic, and give special challenges to the young generation. In this regard, delinquency of children commits a crime both alone or in groups.

According to Wagiati Soetedjo, the child delinquency is an act or a violation of the norm, both legal norms and social norms conducted by young children (Wagiati Soetedjo, 2008). Furthermore, his opinion, child mischief as delinquency which is not the child crime, because it is too extreme, if a child commits a crime is said or labeled as a criminal, while the incident is a natural process which it is not every human experience.

According to Romli Atmasasmita $(1992)^{3}$ the child delinquency: first, the stamp or label attracts attention the observer which be given by the observer; second, the label or stamp be influenced by a person, so acknowledges itself as the stamp or label who is given by the observer. These processes can increase the behavior of deviation and form a criminal career. A person has obtained a stamp or label by itself who will be the attention of the people around him. Furthermore, the vigilance or concern of those around him will affect the person and crimes will be possible again.

In the Indonesian Criminal Code, a crime must contain elements:

1. The existence of human actions;

2. The act must be in accordance with the provisions of the law;

3. An error;

4. People who do should be accountable. 
Based on the above provisions that the person commits something so he must accountable. He knows the act is prohibited by applicable law. A child is a certain age, he has not been able to be categorized as an adult who knows the consequences of his actions, so he can be accountable for all the actions he chooses because of he is an adult position. But the child, in this case, has unstable psychology.

His action is a manifestation of puberty without any intention to harm others as what is implied in a criminal act (Criminal Code), that know and aware the consequences of his actions and the perpetrators can be responsible.

\subsection{Relativisme of Delinquency Culture}

A culture of delinquency or violence among children is very much happening, both in big cities and small towns. Such deeds are essentially either from themselves or others. Usually delinquency or violence background from economic conditions and the surrounding community. Criminal acts are secretly and blatant. Crime is still a unity with poverty, including poor science, poor self-esteem, poor hearts and many others.

That criminology is a science of crime. Criminology as a science must be able to provide benefits for the person who studies. Benefits of criminology include

1. To overcome the crime that exists in society;

2. Eliminating thoroughly;

3. Assisting the People's Legislative Assembly in the drafting of the Law on the

Establishment of Criminal Law.

4. To avoid negative feelings or to avoid unhealthy and unhealthy sympathy for the offender

5. Increase the horizon of the criminal law itself which in this case will be known later in criminal law the term criminalization, decriminalization, penalization, depenalization.

The establishment purpose of a science of criminology as a tools analysis to examine, explore and understand the subject matter, so the criminology theory aims to:

1. Provide a conceptual framework to aid careful observation and description of the crime and social reactions to crime.

2. Formulate a system of basic postulates can explain crime and social reactions.

3. Upholding a basis of knowledge and methods so that under certain circumstances enabling control of crime and social reactions.

4. Forming a conception of criminal justice work.

Thus, criminology is very important to development in assisting the disclosure of delinquency of children who leads to alleged violations and crimes for criminal law enforcement.

\subsection{The Kriminology Of Child Delinquency}

According to experts the definition of Criminology as follows (Topo Santoso dan Eva Achjani Zulfa, 2010) $\left[{ }^{4}\right]$, sebagai berikut :

According to Bonger, the definition of Criminology is a science that aims to investigate the symptoms of crime as possible.

The definition of Criminology by Sutherland is the whole science that binds to crime deeds, which are categorized as social phenomena. Sutherland says that criminology includes processes of legal action, violation of law and reaction to lawlessness. 
The definition of Criminology by Thorsten Sellin extend by adding conduct norms as one of the scopes of criminology research, so the emphasis here is more as a social phenomenon in society.

According to Soedjono Dirjosisworo $(1984)^{5}$, Criminology is a science that studies causation, improvement, the crime as a human phenomenon by collecting various contributions of science.

Elements of criminology According Soedjono Dirdjosisworo

1. Criminology is a science;

2. Who study causes of evil;

3. With the cause of crime consequences then arise awareness to make improvements and prevention

Criminology is a science of crime itself, its object is crime and criminals. The aim is to study the causes so the person commits to a crime which using a methodology both sociological and economic. (Rusli Effendy. 1978) $\left[{ }^{6}\right]$

Romli Atmasasmita $(1984)^{7}$ criminology has two senses is: Criminology in the narrow sense is the study of crime. And Criminology in its broadest sense is the study of penology (developmental punishment) and methods related to crime and the problem of crime prevention with non-punitive actions.

Restrictions on crime in a juridical sense are human behavior that can be punished under Criminal Law. restrictions on criminology, namely: (Soedjono Dirjosiswono 1984) $\left.{ }^{8}\right]$

1. Gaining a picture of human behavior from the social institutions of society that influence the tendencies and deviations of legal norms.

2. Seeking better ways to use criminological understanding in implementing social policies that can prevent or reduce and cope with crime.

Criminology consists both pure and applied criminology. Pure criminology that includes (Bawengan, G.W, 1991) [ $\left.{ }^{9}\right]$ :

1. Criminal anthropology is the science of crime human (somatic). This science provides answers to the question of the crime perpetrator has signs like what? Is there a relationship between tribes with crime and so on.

2. Criminal sociology is the science of crime as a symptom of society. The subject matter is answered by this field of science which causes of crime in society.

3. Criminal psychology, the science see a criminal from his soul.

4. Psychopathology and Criminal Neuropathology is the science of criminals are mentally ill or nerves.

5. Penology is the science of growing and developing of the decide.

Whereas the applied criminology consists of:

1. Criminal hygiene is an attempt to prevent the occurrence of crime, such as the efforts undertaken by the government to apply the law, life insurance system and welfare to prevent the crime.

2. Criminal politics is a crime prevention effort who has occurred in a crime. This is important to know the cause who commit a crime. Example, the cause is economic factors, so the effort improve skills or open employment, thus not with the imposition of sanctions.

3. Criminalism (police scientific) is the science of conducting criminal investigation techniques and criminal prosecution. 
Thus criminology is a collection of a science of crime which the aim can knowledge and understanding of symptoms of crime by studying and analyzing scientifically, uniformities, patterns and causal factors relating to crime, perpetrators of crime and public reaction to both.

Romli Atmasasmita (1992) ${ }^{10}$, formulates criminology is a science uses scientific methods in studying and analyzing order, uniformity of patterns and factors, causes related to crime and criminals, and reactions social to both.

Understanding of criminology According to Soedjono Dirjosisworo (1984) ${ }^{11}$ ], Criminology is a science studies causation, improvement, crime as a human phenomenon. The elements of criminology include:

1. Criminology is science;

2. Who study causes of evil

3. With the cause of crime consequences then arise awareness to make improvements and prevention.

Sutherland developed the theory of Differential Association (Topo Santoso, Eva Achjani Zulfa 2007) ${ }^{12}$ child delinquency due to social relationships. The more social interaction, so the more of delinquency.

Definition crimes according to R. Soesilo (Topo Santoso, Eva Achjani Zulfa 2007) ${ }^{13}$ can be viewed from two perspectives, namely:

1. Definition of Crime from a juridical point of view, Crime is a border of behavior which contrary to the rules of the law.

2. Understanding of crime from a Sociological point of view, Crime is an act or behavior which not only harm the sufferer but also the community. this leads to loss of balance, tranquility and order

Crime cannot escape the lives of the people. A person interacts with the other who can lead to conflict. The definition of crime is an act which violates the rules of society.

According to Howard Becker(Topo Santoso, Eva Achjani Zulfa 2007) $\left[{ }^{14}\right]$, a person is a perpetrator crime which is given to him. The behavior of a person is influenced by the stamp of others. Then the stamp is attached to him who commits a crime.

An act is a crime or violates the law which fulfills of crime elements is:

1. The first element of a crime is an act which causes harm to others.

2. The second element of a crime is regulated in the Criminal Law Code.

3. The third element of a crime is the mental element of a person's intention to commit a crime or knowledge that one's action or lack of action would cause a crime to be committed.

4. The fourth element of a crime is the fusion of crime deed and intent.

5. The fifth element of the crime is regulated both deed and injury by the Criminal Law Code.

6. The last element of a crime is a criminal sanction which threatens the act.

\subsection{The countermeasure of Child Delinquency}

The factors of cause is a behavior who deviant among children, this occurs is a conflict between norms prevailing in society and the values of life owned by individuals. 
Child misbehavior in puberty growth is causing unpredictable child behavior, but this is not justified child behavior. However, this puberty needs strict supervision to keep guiding and directing the child well.

One of the other factors must attention is the age friends who have an important role in increasing criminality among children. according to Sutherland, criminal acts are not natural but can learn it. If child delinquency commits brawls and other crime. In terms of social control theory, the delinquency and crime have related with sociological variables, such as family structure, education, and dominant groups.

This social control is caused by three kinds of development of criminology. That is; first, the reaction to labeling and conflict orientation. second, the emergence of the study of Criminal Justice as a new science which brought criminology to become more pragmatic and system oriented. Third, social control theory is a new research technique especially for the behavior of children, namely self report survey.

The problem, the most important is how to find the right solution to solve this problem. So it becomes a serious concern for the whole community that is parents, teachers, schools, community leaders, religious leaders and government who increase supervision as a preventive effort.

Based on the problem of child mischief, then there are several solutions that can be done to overcome or minimize the problem of mischief, among others by:

1. Establish a good environment

As mentioned above, the environment is the most important factor which affecting human behavior. Creation a good generation influence human behavior so it must create a good environment because bad environment makes damage on human behavior.

2. coaching in the family

The first coaching and planting of behavior are within the family. The family is the place of instruction for the child as the formation of moral values and instill the values of goodness to the child so it can become a habit for the child. Errors in shaping behavior if the attention of the family to child coaching is left to the helper because the demands of the needs of both parents must work. There are also parents who can not guide their children because they have no knowledge and bad habits.

3. School form character.

School is a formal educational institution established to provide knowledge in order to facilitate and shape behavior. The role of teachers in educating become role models for children, so that what is expected can be achieved. School is a place to form the character of the child, but not only submitted to the school alone.

The third attempt above is a preventive effort which controls all social change with maintaining a stable (equilibrium) and sustainable (continuity) social system, through two different social mechanisms in the form of socialization and integrated social control, so as to prevent the child from dealing with the law.

In fact, if a child cannot be controlled by his or her family, so the parent may hand over his or her child to the state for upbringing by the state. Parent feel guilty but for correct the child so it can be done. For example, a child is addicted to drugs, steal money to fulfill his wishes and sometimes threatened his parents, so this child's actions cannot be allowed. The parent role report child to the related parties so that to get a comprehensive handling so that children do not traps drug. 
Restorative Justice and Diversity is an alternative effort to solve the problems of children in conflict with the law. In this diversionary effort, the Police Agency may use its discretionary authority. Among others are not holding the child, but setting an action in the form of returning the child to his parents or submit it to the state. At the prosecution level, a diversion attempt cannot be made because the prosecution has no discretionary authority. Whereas at the authority of the court is to impose a jail sentence or imprisonment. Therefore, there should be a clear regulation on the effort to be diverted both at the level of the police, prosecutors and courts as regulated in Law No. 11 the Year 2012 on the criminal justice system of children. So that police officers do not use their authority is not clear, but based on the provisions of applicable law. Then in the implementation of the judicial process of Law No. 3 of 1997 has not prioritized the legal approach with Restorative justice as well as the approach contained in Law No. 11 of 2013 which prioritizes restorative justice approach.

\section{Conclusion}

The Child is 12 to 18 years of age and not married yet. The child is considered that has not knowledge but also has a unique and exclusive personality. but the child has deviant behavior, in perspective criminology, an act is a form of deviant behavior that forms a brat stigma as self-actualization of the child in the association to find the identity. In order, the behavior does not become an act that will deal with the law so handling must also be more comprehensive and integrated, for example, must perform diversion, principles of child protection and so on, in order to prevent child misbehavior..

The child delinquency is a stigma in family or culture which is relative because child delinquency is not universal but relativistic. The tendency of child delinquency due to intrinsic and extrinsic motivation. therefore it is necessary to handle the child delinquency, so as not to become a troubled child or dealing with the law. based on relativism of child delinquency has a standard of delinquency. Every culture of society has values to guide child mischief.

Prevention is the effort to find the problem, such as doing preventive efforts (before the crime) and repressive efforts (after the occurrence of crime). Prevention efforts can be done with the help of another science is Criminalitastik science, this science finds causes a person committed a crime and what caused the crime. While Penology is the science of how to punish a prisoner but not torture in order not to commit crimes again

Restorative Justice is a diversity process. All parties are involved in a particular offense to jointly solve problems and create an obligation to make things better. So it necessarily involves the victim, the child, and the community in finding solutions to reconciliation, reconciliation, and reassurance, there are not based on retaliation. Diversi is the transfer of settlement of child cases from the criminal justice process to proceedings outside the criminal justice.

Not all parents can educate, guide and advise their children well. Obedient children are the hope of all parents, but there are children dare to snarl and beat the parents. So it is necessary to do extreme efforts is to revoke custody of parents or parents. then the parent must be willing to relinquish custody and give it to the State through the Stipulation of the Court to be a Civil Child or a State Child, in the interest of the child as a generation of nation and State. 


\section{References}

[1]. Yesmil Anwar Adang, 2010. Kriminologi, Refika Aditama, Bandung.

[2]. Atmasasmita, Romli. 1983, Problem Kenakalan Anak-Anak Remaja, Armico, Bandung.

[3]. Atmasasmita, Romli. 1992. Teori dan Kapita Selekta Kriminologi, Refika Aditama, Bandung

[4]. Topo Santoso dan Eva Achjani Zulfa, 2010. Kriminologi. Penerbit PT Raja Grafindo Persada : Jakarta.

[5]. Dirdjosiswoyo, Soedjono, 1984. Ruang Lingkup Kriminologi, Remaja Karya, Bandung.

[6]. Effendy, Rusli. 1978. Asas-Asas Hukum Pidana. LEPPEN-UMI, Ujung Pandang.

[7]. Atmasasmita, Romli. 1984. Bunga rampai kriminologi. Rajawali. Jakarta.

[8]. ibid

[9]. Bawengan, G.W, 1991. Pengantar Psikologi Kriminal, Pradnya Paramita, Jakarta

[10]. Atmasasmita, Romli. 1992. Teori dan Kapita Selekta Kriminologi, Refika Aditama, Bandung.

[11]. ibid

[12]. ibid

[13]. ibid

[14]. ibid 